\title{
Olumsuz Denetim Görüşü ve Bağımsız Denetçi Değişikliği Arasındaki İlişki: Borsa İstanbul Sanayi Şirketleri Üzerine Bir Uygulama
}

Alpaslan YAŞAR*

\section{$\ddot{O Z Z T}$}

Bu çalışma, Türkiye'de olumsuz denetim görüşü ve bă̆ımsız denetçi değişikliği arasındaki ilişkiyi incelemektedir. Bu ilişki, Borsa Istanbul'da 2003-2009 döneminde işlem gören sınai işletmeler örnekleminde, parametrik olmayan Ki-kare bağımsızlık testi kullanılarak analiz edilmiştir. Sonuçlar, olumsuz denetim görüşü ve bağımsız denetçi değişikliği arasında anlamlı bir ilişki olduğunu göstermiştir. Bu sonuç, şirket yöneticilerinin olumsuz görüss sonrası denetçi değiştirdiklerine işaret etmektedir. Fakat, olumsuz görüş sonrası denetçi değiştiren şirketler, izleyen yilda muhtemelen olumlu denetim görüşü alamamaktadırlar. Bununla birlikte, olumlu görüş alma olasılı̆̆l, önceki yıldaki olumsuz görüş türünden bağımsız iken, denetçi türüne bağımlı çıkmıştır.

Anahtar Kelimeler: Denetçi Değişikliği, Olumsuz Görüş, Olumlu Görüş.

JEL Sınıflandırması: M41, M42, M48.

The Relationship Between Qualified Audit Opinions and Auditor Switching: An Application on Industry Firms of Istanbul Stock Exchange

\section{ABSTRACT}

This study examines the association between qualified opinions and auditor switches in the context of Turkey. This relationship is analyzed by using non-parametric Chi-square test based on the sample of industry firms listed on Istanbul Stock Exchange over the 2003-2009 period. The results showed that there is significant association between qualified opinions and auditor switch. This result indicate that managers switches auditors following qualified opinions. However, switching firms after a qualified opinion are not more likely to receive a unqualified opinion the following year. In addition, the likelihood of an unqualified audit opinion is independent of the type of prior year qualification and however, dependent on auditor type.

Keywords: Auditor Switching, Qualified Opinions, Unqualified Opinion.

Jel Classification: M41, M42, M48.

\footnotetext{
* Yrd. Doç. Dr. Alpaslan Yaşar, Osmaniye Korkut Ata Üniversitesi, İktisadi ve İdari Bilimler Fakültesi, alpaslanyasar@osmaniye.edu.tr
} 


\section{GİRiş}

Bilindiği üzere, finansal bilgi kullanıcılarının aldıkları kararlara dayanak teşkil eden mali tablolarda sunulan bilgilerin güvenilirliğinin arttırılmasında ve dolayısıyla bilgi riskinin azaltılmasında bağımsız dış denetim önemli bir rol oynamaktadır. Buna bağlı olarak, denetim görevini yerine getiren bağımsız denetçinin bağımsız olması gerektiği düşüncesi, bağımsız denetim mesleğinin önemli bir yapı taşını oluşturmuştur. Özellikle, 2001 yılı sonlarında ABD'de ortaya çıkan Enron skandalı ve sonrasındaki muhasebe skandallarında, işletme ve denetim firması arasında 'denetim görüş alış-verişi' (opinion shopping) yaşandığı yönündeki iddialar, denetçi bağımsızlığına verilmesi gereken önemi artırmıştır.

Bağımsız denetçinin temel sorumluluğu, bir şirket tarafindan hazırlanan finansal tabloların şirketin performansı ve finansal durumunu doğru ve dürüst bir şekilde yansıttığı hususunda görüş vermektir. Bu görevi gerçekleştirecek olan bağımsız denetçi, normal muhasebe uygulamalarından sapmalar konusunda yönetimin dikkatini çekmekten sorumludur. $\mathrm{Bu}$ durumda, yanlışlıkların tek başına ya da toplu olarak finansal tablolar için önemli ve (etkisinin) yaygın olduğu sonucuna varılması durumunda, olumsuz denetim görüşü verilmesi söz konusu olacaktır. Ancak, bağımsız denetim raporu hissedarlar, kreditörler gibi bilgi kullanıcılarının firma değerlemesi ile ilgili kararlarında kullanılacağı için, yayımlanan raporun türü işletme yönetimi açısından önem taşıyacaktır. Dolayısıyla, yönetimin zayıflığını açık bir şekilde ortaya koyan olumsuz denetim raporunu yönetim kabul etmek istemeyecektir. Bu tür olumsuz bir raporun bilgi kullanıcılarının işletme yönetimi ile ilgili algılaması üzerinde negatif etkileri olabileceği için, yönetim her zaman olumsuz denetim görüşünden kaçınmak isteyecek ve olumlu denetim görüşü almaya yönelik işten çıarma tehdidiyle mevcut denetçilere baskı uygulayabilecektir (Chow ve Rice, 1982). Bu kapsamda, Chow ve Rice (1982) çalışmasında, olumsuz denetim görüşünün şirket hisselerinin piyasa değerini ve/veya yöneticilerin teşvik primlerini (raporlanan kâr'a ve olumsuz bir denetim görüşü verildiğinde gündeme gelen söz konusu raporların güvenilirliğine bağlı olabilmektedir) azaltmak gibi bir dizi maliyetlerinin olduğunu ve bunu öngören yöneticinin, olumsuz denetim sonrası büyük bir ihtimalle denetçi değişikliğine gideceği belirtilmiştir. Whittred (1980), denetim görüşünün olumsuz olduğu durumda, ilave denetim maliyetleri nedeniyle denetim sürecinin uzadığı ve buna bağlı olarak faaliyet raporlarında geçikme olduğu sonucuna ulaşmıştır. Dolayısıyla, hem Chow ve Rice (1982) hem de Whittred (1980) olumsuz denetim görüşleri ile ilişkili maliyetlerin olumsuzluğun önem düzeyinin bir fonksiyonu olduğunu öne sürmüşlerdir. Bu kapsamda, Craswell (1988) olumsuzluğun önem düzeyinin finansal bilgi kullanıcısının algılamasına bağlı olduğunu belirtmiş ve 'olumsuz' ve 'görüş bildirmekten kaçınma' şeklindeki raporları önemli olumsuzluklar olarak çalışmasında dikkate almıştır.

Literatürde, denetçi değişikliğini etkileyen faktörler olarak; olumsuz denetim görüşü, yönetimdeki değiş̧iklikler, denetim ücreleri, finansal sıkıntı, denetim firmasının türü, işletme büyüklüğü, işletme birleşmeleri gibi değişkenler kullanılmakla birlikte, olumsuz denetim görüşü denetçi değişikliğinin önemli nedenlerinden biri olarak görülmüştür. Bu kapsamdaki 
çalışmalarda (Örneğin; Chow and Rice, 1982; Craswell, 1988); şirketlerin olumlu denetim raporu almak amacıyla bağımsız denetçilerini değiştirdikleri öne sürülmüştür.

Olumsuz denetim görüşü ${ }^{1}$ ve denetçi değişikliği arasındaki ilişkiyi farklı yöntemler kullanarak araştıran çeşitli çalışmalar bulunmakla birlikte, Türkiye gibi gelişmekte olan ve bağımsız dış denetim kalitesinin sorgulandığı ülkelerde bu nitelikte çalışma sayısı sınırlıdır. $\mathrm{Bu}$ nedenle, bu çalışmada sadece denetçi değişikliğini etkileyen en önemli faktörlerden biri olarak kabul edilen olumsuz denetim görüşlerinin etkisi incelenmiştir. Bu kapsamda, çalışmanın amacı; olumsuz denetim görüşü ve sonrasındaki bağımsız denetçi değişiklikleri arasındaki ilişkiyi Türkiye'deki denetim ortamında incelemek suretiyle önceki benzer çalışmalarla karşılaştırma yapma imkanı sağlamaktır. Bu amaçla, olumsuz denetim görüşü ve izleyen yılda olumlu denetim görüşü almaya yönelik denetçi değişikliği arasında anlamlı bir ilişkinin olup olmadığ Ki-kare bağımsızllk testi uygulanarak test edilmiştir.

$\mathrm{Bu}$ çerçevede, ikinci bölümde, Türkiye'de denetim görüşü ve denetçi değişikliğinin yasal düzenlemelerde ve düzenleyici kurumların (Kamu Gözetim Kurumu, SPK, BDDK) düzenlemelerindeki yeri açıklanmıştır. Konu ile ilgili teorik ve önceki çalışmalarla ilgili bilgiler üçüncü bölümde incelenirken, çalışmanın araştırma yöntemi dördüncü bölümde açıklanmıştır. Beşinci bölümde, çalışmada elde edilen bulgulara yer verilmiş ve son bölümde çalışmanın sonuçları ortaya konularak, geleceğe ilişkin araştırma önerilerinde bulunulmuştur.

\section{TÜRKIYE'DE DENETIM GÖRÜŞÜ VE DENETÇI DEĞişiKLIĞGiNiN YASAL DÜZENLEMELERDEKİ YERI}

Türkiye'de bağımsız denetim görüşü ve denetçi değişikliğine ilişkin yasal düzenlemeler incelendiğinde; Sermaye Piyasası Kurulu (SPK), Bankacıllk Düzenleme ve Denetleme Kurumu (BDDK), Hazine Müsteşarllğı ve Enerji Piyasası Düzenleme Kurumu tarafindan gerçekleştirilen düzenlemelerin, 2 Kasım 2011 tarihinden itibaren ise Kamu Gözetimi, Muhasebe ve Denetim Standartları Kurumunca yapılan düzenlemeler ve sonrasında 6102 Sayılı Yeni Türk Ticaret Kanunu ile yapılan yasal düzenlemelerin etkili olduğu görülmektedir.

Türkiye'de bağımsız denetim görüşü kapsamındaki düzenlemeler ile ilgili olarak, Sermaye Piyasası Kurulu, bağımsız denetim alanında yapılan önemli düzenlemelerden biri olan Seri: X, No:22 Sayılı Sermaye Piyasasında Bağımsız Denetim Standartları Hakkında Tebliğin Yirmidokuzuncu ve Otuzuncu Kısımlarında bağımsız denetim görüşleri ile ilgili hususları düzenlemiştir ${ }^{2}$. Söz konusu Tebliğin Yirmidokuzuncu Kısmı, genel amaçlı tam set finansal tabloların bağımsız denetim sonucu hazırlanan bağımsız denetim raporları ile söz

\footnotetext{
${ }^{1} \mathrm{Bu}$ çalışmada, 'olumsuz denetim görüşü' ibaresi literatürdeki kullanımına benzer şekilde; şartlı, görüş bildirmekten kaçınma ve olumsuz görüş şeklin deki denetim görüşlerini de kapsayacak şekilde kullanılmıştır.

${ }^{2}$ 12.06.2006 tarih ve 26196 sayılı Resmi Gazete'de yayımlanan Seri: X, No:22 sayılı Sermaye Piyasasında Bağımsız Denetim Standartları Hakkında Tebliğ; 2006, 2008, 2009, 2011 ve en son olarak da 28.06.2013 tarihinde Seri:X, No:28 sayılı Tebliğ ile değişikliğe uğramıştır.
} 
konusu finansal tablolara ilişkin bağımsız denetim görüşü oluşturulmasında dikkate alınacak ilke, usul ve esasları belirlemekte olup, bağımsız denetçinin olumlu görüş vermesinin mümkün olduğu hallerde bu Kısım hükümleri uygulanmaktadır. Tebliğin Otuzuncu Kısmında ise, bağımsız denetim raporunda şartlı veya olumsuz görüş verilmesi ya da görüş bildirmekten kaçınılması durumlarında raporlamaya ilişkin izlenecek usul ve esaslar ile bu durumlarda düzenlenecek bağımsız denetim raporlarının şekil ve içeriğine dair ilke, usul ve esaslar düzenlenmiştir. Bağımsız denetim görüşü kapsamında diğer bir düzenleme Bankacılık Düzenleme ve Denetleme Kurumu (BDDK) tarafından yapılmıştır. BDDK, bankaların bilgi sistemleri ile bankacılık süreçlerinin yetkilendirilmiş bağımsız denetim kuruluşları tarafından denetlenmesi ile ilgili usul ve esasları, 13 Ocak 2010 tarihli 'Bağımsız Denetim Kuruluşlarınca Gerçekleştirilecek Banka Bilgi Sistemleri ve Bankacılık Süreçlerinin Denetimi Hakkında Yönetmelik’ ile düzenlemiştir. Ayrıca, söz konusu yönetmelik kapsamında hazırlanacak olan denetim raporunun içerik ve şekline ilişkin usul ve esaslar, 'Bağımsız Denetim Kuruluşlarınca Gerçekleştirilecek Banka Bilgi Sistemleri ve Bankacılık Süreçlerinin Denetimine ilişkin Rapor Hakkında Tebliğ' ile açıklanmıştır. Bağımsız denetim görüşü ile ilgili bir diğer düzenleme, Enerji Piyasası Düzenleme Kurumu (EPDK) tarafından çıkarılan, 3 Ekim 2003 tarihli ‘Enerji Piyasasında Faaliyet Gösteren Geerçek ve Tüzel Kişilerin Bağımsız Denetim Kuruluşlarınca Denetlenmesi Hakkında Yönetmelik' ile yapılmış olup, yönetmeliğin üçünücü bölümü, bağımsız denetim raporuna ilişkin hükümleri içermektedir.

Kamu Gözetimi Muhasebe ve Denetim standartları Kurumunun, Yeni Türk Ticaret Kanunu uyarınca öngörülen bağımsız denetim alanını düzenlemek üzere, 2 Kasım 2011 tarihinde 660 sayılı Kanun Hükmünde Kararname ile kurulmasıyla, SPK, BDDK, EPDK, Hazine Müsteşarlığı gibi çok sayıda kuruluş tarafından yapılan denetim tek bir kurumda toplanmıştır. Kamu Gözetimi Muhasebe ve Denetim Standartları Kurumu, 1/1/2013 tarihinde ve sonrasında başlayacak hesap dönemlerinden itibaren uygulanmak üzere, 'Bağımsız Denetim Raporunda Olumlu görüş Dışında Bir Görüş Verilmesi’ başlıklı 705 no.lu Bağımsız Denetim Standardını 31 No.lu Türkiye Denetim Standardı Tebliği ile yürürlüğe koymuştur. Söz konusu standart, denetçinin Bağımsız Denetim Standardı 700 uyarınca bir görüş oluştururken, finansal tablolara ilişkin olumlu görüş dışında bir görüş vermesi gerektiği sonucuna varması durumunda, içinde bulunulan şartlara uygun bir rapor düzenleme sorumluluğunu düzenlemektedir. Bu kapsamda, olumlu görüş dışında bir görüş verileceği zaman kullanılacak, sınırlı olumlu görüş (şartlı görüş), olumsuz görüş ve görüş vermekten kaçınma şeklinde üç farklı görüş türü belirlenmiştir. Söz konusu standarda göre; denetçi, elde edilen denetim kanıtlarına dayanarak, bir bütün olarak finansal tabloların önemli yanlışlık içerdiği sonucuna varırsa veya bir bütün olarak finansal tabloların önemli yanlışlık içermediği sonucuna varmak için yeterli ve uygun denetim kanıtı elde edemezse, olumlu görüş dışında bir görüş verecektir. Buna göre; denetçi, yanlışlıkların tek başına veya toplu olarak önemli olduğu ancak finansal tablolarda yaygın olmadığı sonucuna varırsa veya tespit edilmemiş yanlışlıkların finansal tablolar üzerindeki muhtemel etkilerinin önemli olabileceği ancak 
yaygın olmayabileceği sonucuna varırsa sınırlı olumlu görüş (şartlı görüş) verecektir. Eğer, yeterli ve uygun denetim kanıtı elde etmiş olan denetçi, yanlışlıkların tek başına veya toplu olarak finansal tablolar için önemli ve etkisinin yaygın olduğu sonucuna varırsa olumsuz görüş verecektir. Diğer taraftan, denetçi, görüşüne dayanak teşkil edecek yeterli ve uygun denetim kanıtı elde edemezse ve -varsa- tespit edilmemiş finansal yanlışlıkların finansal tablolar üzerindeki muhtemel etkilerinin önemli ve yaygın olabileceği sonucuna varırsa veya, finansal tablolara ilişkin görüş oluşturmanın mümkün olmadığı sonucuna varırsa, görüş vermekten kaçınacaktır. Bağımsız denetim alanında yapılan önemli düzenlemelerden birisi de 6102 sayılı Türk Ticaret Kanununun 'Denetleme' başlıklı 397 ile 406 maddeleri arasında yapılmış olup, Kanunun 402 ve 403 . maddelerinde, denetim raporu ve görüş yazıları ile ilgili düzenlemelere yer verilmiştir. Bu kapsamda, Kanunun 'Görüş Yazıları' başlıklı 403. maddesinde; olumlu görüş, sınırlandırılmış olumlu görüş, olumsuz görüş ve görüş vermekten kaçınma şeklinde dört tür denetim görüşüne yer verilerek, hangi durumlarda hangi tür denetim raporlarının düzenlenmesi gerektiği belirlenmiştir.

Türkiye'de halka açık şirketlerdeki bağımsız denetçi değişiklikleri ile ilgili yasal düzenlemeler incelendiğinde, SPK'nın 2002'de yayımlanan Seri:X No:19 sayılı Tebliğ ile bağımsız denetim kuruluşlarına yönelik 5 yıllık rotasyon zorunluluğu getirdiği ancak daha sonra 2006'da yayımlanan Seri:X No:22 sayılı Tebliğ'de, bağımsız denetim kuruluşlarına yönelik bu zorunluluğun 7 yıla çıkarıldığı görülmektedir. Fakat, bu zorunluluk, 26.03.2011 tarihli Seri:X No: 28 sayılı Tebliğle yapılan değişiklikle, bağımsız denetim kuruluşlarının seçimine yönelik 7 yıllık azami süre kuralından muafiyet getirilmiştir. Buna göre; 1/1/2011 tarihinden sonra sona erecek hesap dönemlerinden itibaren geçerli olmak üzere, bağımsız denetim kuruluşu rotasyonu yerine sorumlu ortak başdenetçi rotasyonu getirilmiştir. Bu kapsamda, bir sorumlu ortak başdenetçinin bir müşteri ile yapılan bağımsız denetim sözleşmesinde, her halükarda en çok 5 hesap dönemi görev alabileceği ve söz konusu sorumlu ortak başdenetçinin tekrar aynı müşterinin denetim çalışmalarında görev alabilmesi için en az iki hesap dönemi geçmesi gerektiği hükme bağlanmıştır.

\section{LITERATÜRDEKİ ÇALIŞMALAR}

Denetçi değişikliği, önceki akademik çalışmalarda önemli bir araştırma konusu olarak incelenmiş ve denetçi değişikliğinin nedenleri ile ilgili çeşitli araştırmalar gerçekleştirilmiştir. Literatürde, denetçi değişikliğini etkileyen faktörler olarak genellikle olumsuz denetim görüşü (Chow and Rice, 1982; Schwartz and Menon, 1985; Williams, 1988; Craswell 1988; Haskins and Williams, 1990; Dye, 1991; Teoh, 1992; Gul et al., 1992; Krishnan et al., 1996; Lennox, 2000; Woo and Koh, 2001; Vanstraelen, 2003), yönetimdeki değişiklikler (Burton and Roberts, 1967; Carpenter and Strawser, 1971; Hudaib and Cooke, 2005), müşteri işletmenin büyüklüğ̈̈ (Gul et al., 1992; Krishnan et al., 1996; Willenborg, 1999), denetim firmasının türü (Warren, 1980; Chow and Rice, 1982; Craswell, 1988; Krishnan et al., 1996), denetim ücretleri (DeAngelo, 1981; Wines, 1994; DeFond et al. 2002; Craswell et al. 2002), finansal 
s1kıntı (financial distress) (Schwartz and Menon, 1985; Hudaib and Cooke, 2005) gibi değişkenler kullanılmıştır.

Denetçi değişikliği kapsamındaki çalışmalarda; olumsuz denetim görüşü, denetçi değişikliğinin en önemli nedenlerinden biri olarak incelenmiş ve haklarında olumsuz denetim görüşü verileceğini düşünen şirketlerin, bağımsız denetçiyi işten çıkarma tehdidinde bulunacakları yönünde çok sayıda atıfta bulunulmuştur. $\mathrm{Bu}$ durum, literatürde genellikle 'denetim görüşü alışverişi ${ }^{3}$ (opinion shopping) olarak ifade edilmiş ve şirketlerin olumlu denetim raporu verilmesini arzu ettikleri belirtilmiştir. Bu kapsamdaki çeşitli çalışmalarda, denetçi değişikliği ve olumsuz denetim görüşü arasında pozitif bir ilişki bulunmuştur (Chow and Rice, 1982; Craswell, 1988; Gul et al., 1992; Citron and Tafler, 1992; Krishnan et al., 1996; Lennox, 2000; Vanstraelen, 2003). Örneğin; Chow and Rice (1982) bulgular1, firmaların olumsuz denetim görüşü sonrasında denetçi değişikliğine yönelecekleri iddiasını desteklemektedir. Ayrıca, söz konusu çalışmada; olumsuz denetim görüşü sonrasında denetçi değiştiren şirketlerin, denetçi değiştirmeyen şirketlerle karşılaştırıldığında, izleyen yılda olumlu denetim raporu alma ihtimallerinin yüksek olmadığı sonucuna ulaşmışlardır. Craswell (1988) Avustralya örnekleminde gerçekleştirdiği çalışmasında, yöneticilerin olumsuz denetim görüşü sonrasında çoğunlukla denetçi değişikliğinde bulundukları ve yeni denetçilerin olumlu denetim görüşü verdikleri sonucunu elde etmiştir. Bununla birlikte, söz konusu çalışmada; olumlu denetim görüşü alma olasılığının, olumsuz denetim görüşünün türü ve denetim firması büyüklüğünden (8 Büyükler veya Diğerleri) bağımsız olduğu sonucuna ulaşılmıştır. Gul et al. (1992), Hong Kong şirketleri örnekleminde gerçekleştirilen çalışmada, Chow and Rice (1982) çalışma sonuçları ile tutarlı olarak, olumsuz denetim raporu ve sonrasındaki bağımsız denetçi değişikliği arasında anlamlı bir şekilde pozitif bir ilişki olduğunu göstermiştir. Fakat, bu denetçi değişikliği davranışının, sonrasında olumlu rapor verilmesini sağlamadığı sonucuna ulaşmıştır. Benzer şekilde, Citron and Tafler (1992), Chow and Rice (1982) çalışması ile tutarlı sonuçlar bulunmuştur. İngiltere halka açık şirketleri örnekleminde 1977-1986 dönemi esas alınarak gerçekleştirlen söz konusu çalışmada, işletmenin sürekliliği ile ilgili belirsizlik kapsamındaki olumsuz denetim raporu ile denetçi değişikliği arasında pozitif bir ilişki olduğu öne sürülmüştür. Bununla birlikte, Krishnan et al. (1996) çalışmasında, olumsuz denetim görüşünün denetçi değişikliği üzerinde pozitif bir etkisi olduğu yönündeki önceki çalışma sonuçlarını (Chow and Rice, 1982; Craswell, 1988; Citron and Tafler, 1992) doğrulayan nitelikte bulgular elde edilmiştir. Dye (1991), bağımsız denetçi ve müşterinin, şirketin finansal durumu hakkında ortak bilgiye sahip olmaları durumunda, genellikle, denetçinin değiştirilmeyeceğini; müşterinin bağımsız denetçiye göre daha üstün bir bilgiye sahip olması ve denetçinin muhtemelen şartlı denetim raporu verecek olması durumunda ise, bağımsız denetçinin büyük bir ihtimalle, müşteri işletmeye uygun yeni bir

\footnotetext{
${ }^{3}$ İngilizce literatürde 'opinion shopping' olarak ifade edilen ve Türkçe'ye 'denetim görüşü alışverişi' olarak çevirebilecek bu kavram; bağımsız denetçinin olumsuz denetim görüşü verebileceğine inanan bir şirketin, bu durumdan kaçınmaya yönelik olarak bağımsız denetçinin işine son verdiği bir uygulamadır.
} 
denetçi ile değiştirileceğini öne sürmüştür. Teoh (1992) çalışmasında, olumsuz denetim raporu sonrasında daha fazla denetçi değişikliği görülme sıklı̆̆ının, bağımsız denetçinin yönetimin isteklerine uymak yerine mekanik bir karar kuralını izlemesi ile tutarlı olduğu tartışılmıştır. Lennox (2000), İngiltere şirketleri örnekleminde gerçekleştirdiği çalışmasında, şirketlerin 'denetim görüşü alışverişi'ni başarılı bir şekilde uyguladıkları bulgusu elde edilmiştir. Söz konusu çalışmada iki önemli bulguya ulaşılmıştır. Birincisi, olumsuz denetim görüşü alan şirketlerin çoğunlukla bağımsız denetçilerini değiştirdikleridir. İkinci önemli bulgu ise olumsuz denetim raporu sonrası bağımsız denetçi değişikliğinin, daha uygun (olumlu) denetim görüşü verilme olasılığını artırmasıdır. Vanstraelen and Ann (2003) çalışmasında, Lennox (2000) çalışma sonuçları ile tutarlı şekilde, işletmenin sürekliliği kapsamındaki denetim görüşü ile ilgili olarak şirketlerin büyük olasılıkla izleyen yılda denetçilerini değiştirdikleri yönünde anlamlı bulgular elde edilmiştir.

Olumsuz denetim raporu ve bağımsız denetçi değişikliği arasındaki ilişkiyi araştıran bazı çalışmalarda, denetim raporu ve denetçi değişikliği arasında anlamlı bir ilişki bulunmadığı yönünde sonuçlar elde edilirken (Schwartz and Menon, 1985; Williams, 1988; Haskins and Williams, 1990), bir kısım çalı̧̧malarda ise negatif bir ilişkinin bulunduğu yönünde sonuçlar elde edilmiştir (Woo and Koh, 2001). Bu kapsamda, Schwartz and Menon (1985) and Haskins and Williams (1990) denetçi değişikliği ve bağımsız denetim görüşü arasında anlamlı bir ilişki bulamamışlardır. Schwartz and Menon (1985), denetçi değişikliğinin şirketin finansal durumuna bağlı olarak değişebileceği ileri sürülmüştür. Bununla birlikte, Haskins and Williams (1990) çalışmasında; denetim görüşü değişkeninin nispeten önemsiz bir denetçi değişikliği faktörü olduğu, oysaki, işletmenin finansal sıkıntısı, işletmenin büyüklüğü, büyüme, denetim firmasının pahalılığı ve sektör üstünlüğü gibi değişkenlerin denetçi değişikliği ile ilgili en önemli faktörler olduğu sonucu elde edilmiştir. Diğer taraftan, Woo and Koh (2001) çalışmasında ise, olumsuz denetim görüşü ile denetçi değişikliği arasında negatif bir ilişki olduğu sonucu elde edilmiştir.

\section{ARASTIRMANIN YÖNTEMI}

Olumsuz denetim görüşü ve bağımsız denetçi değişikliği arasındaki ilişkinin araştırıldığı bu çalışmada, Borsa İstanbul (BIST) sınai endeks'te 2003-2009 döneminde kesintisiz işlem gören şirketlerin yıllık faaliyet raporları incelenmek suretiyle elde edilen veriler kullanılmıştır. Bu kapsamda, çalışmanın örneklemini sanayi sektöründe yer alan ve verilerine ulaşılabilen 153 şirkete ait 1.071 şirket-yll verisi oluşturmakta olup, inceleme döneminde 143 olumsuz denetim görüşü verilmiştir ${ }^{4}$. Bu çalışmada, Craswell (1988)

\footnotetext{
${ }^{4}$ Literatürde olumsuz denetim görüşleri; şartlı görüş, görüş bildirmekten kaçınma ve olumsuz görüş olarak üç grupta sınıflandırılmakta olup, söz konusu 153 şirkete ilişkin toplam 143 adet olumsuz denetim görüşleri sayısının içerisinde; 6 şirkete ait (Boyasan Tekstil-2009; ÇBS Boya-2008,2009; ÇBS Printaş-2008,2009; Emek Elektrik-2003; Gediz İplik-2009; Meges Boya-2008,2009) 9 adet 'Görüş Bildirmekten Kaçınma', 134 adet 'Şartlı Görüş’ yönünde bağımsız denetim raporu bulunurken, 'Olumsuz Denetim Raporu' bulunmamaktadır.
} 
çalışmasına benzer şekilde, sadece, ilk olumsuz denetim görüşü ve bu ilk olumsuz denetim görüşü sonrasındaki 5 yıl içerisinde bu şirketlerde meydana gelen bağımsız denetçi değişiklikleri incelenmektedir. Bu çalışmanın argümanı, olumsuz denetim görüşü sonrasında denetçi değişikliği yapmak suretiyle olumlu bir denetim görüşü elde edilebileceği ve olumsuz denetim görüşü sonrasındaki muhtemel maliyetlerden kaçınılabileceği varsayımına dayandırılmaktadır.

Literatürdeki bazı çalışmalarda (Chow and Rice, 1982; Craswell, 1988), denetçi değişikliğinin olumsuz denetim raporu alınmasından hemen sonraki yllda meydana gelmesi durumunda, bağımsız denetçi değişikliği ile olumsuz denetim raporu arasında ilişki olduğu varsayılmaktadır. $\mathrm{Bu}$ yaklaşım, şirketlerin olumlu denetim raporu almak amacıyla bağımsız denetçilerini değiştirdiklerini varsaymaktadır. $\mathrm{Bu}$ nedenle, bir şirket olumsuz denetim raporunun hemen sonrasındaki yılda bağımsız denetçisini değiştiriyorsa, olumsuz denetim görüşünün denetçi değişikliği kararını etkilemesi muhtemeldir. Bir şirketin denetçi değiştirmesinin yönetim değişiklikleri, finansal sıkıntı, işletme büyüklüğü, denetim ücretleri gibi çeşitli nedenleri bulunmaktadır. Fakat, yönetimin denetçi değiştirme kararındaki veya bağımsız denetçinin olumsuz denetim raporu verme kararındaki gerçek amacı anlamak zordur (Sriram, 1990). Bu nedenle, bu çalışmada sadece olumsuz denetim görüşü ve sonrasındaki bağımsız denetçi değişikliği arasındaki ilişki incelenmişir. Bu şekildeki bir yaklaşım aynı zamanda önceki benzer çalışmalarla karşılaştırma yapma imkanı sağlamaktadır (Chow and Rice, 1982; Craswell, 1988).

$\mathrm{Bu}$ çalışmada; olumsuz denetim görüşü ve izleyen yılda olumlu denetim görüşü almaya yönelik denetçi değişikliği arasında anlamlı bir ilişkinin olup olmadığını belirlemek amacıyla Ki-kare bağımsızlık testi uygulanmıştır.

\section{ARAŞTIRMA BULGULARI}

Bu çalışmada, Craswell (1988) çalışmasına benzer şekilde, sadece, sanayi sektöründe yer alan şirketlerle ilgili ilk olumsuz denetim görüşü ve bu ilk olumsuz denetim görüşü sonrasındaki 5 yıl içerisinde bu şirketlerde meydana gelen bağımsız denetçi değişiklikleri incelenmiş olup, bu kapsamda elde edilen sonuçlar aşağıda sunulmuştur.

\subsection{Olumsuz Denetim Raporu Sonrasındaki Bağımsız Denetçi Değişikliği}

Olumsuz denetim görüşü sonrasındaki denetçi değişikliklerinin sıklıkığı Tablo 1'de sunulmuştur. Tablo 1, ilk olumsuz denetim görüşünü izleyen y1l 13 şirketin denetçi değiştirdiğini göstermektedir. Buna göre, 143 olumsuz denetim görüşü sonrasındaki 5 yıl içerisinde meydana gelen toplam 25 denetçi değişikliğinden 13'ü (\%52) ilk olumsuz denetim görüşünün verildiği yılı izleyen yılda gerçekleşmiştir. 


\subsection{Olumsuz ile Olumlu Görüş Verilen Şirketlerin İzleyen Yıldaki Denetçi Değişikliği}

İlk analiz olarak, olumsuz denetim görüşü verilen şirketler ile kontrol grubu olarak seçilen olumlu denetim görüşü verilen şirketlerin, izleyen ilk yıldaki denetçi değişiklikleri incelenmiştir. Bu kapsamda, 2003-2009 döneminde sanayi sektörü şirketlerinin olumlu denetim raporları içerisinden rastgele belirlenen yaklaşık \% 15'i (140 olumlu rapor) karşılaştırma grubu olarak seçilmiştir. Bununla birlikte, Craswell (1988) çalışmasına benzer şekilde, denetçi değişikliğinin izleyen yıl içerisinde meydana gelip gelmediğine göre çalışmanın örneklemi Tablo 2'de görüldüğü gibi bölümlendirilmiştir.

$\mathrm{Bu}$ çerçevede, olumsuz denetim görüşü ile olumlu denetim görüşü verilen şirketlerin denetçi değişiklikleri sıklığı Ki-kare test değerleri ile birlikte Table 2'de sunulmuştur. Buna göre, ilk olumsuz denetim raporunu izleyen yıl için denetçi değişikliği oranının (0.09), kontrol grubu olarak oluşturulan ve olumlu denetim görüşü verilen şirketlerin izleyen ilk yıldaki denetçi değişikliği oranından (0.01) anlamlı şekilde daha fazla olduğu görülmektedir. Tablo 2'den görüldüğü üzere; 8.28 Ki-kare değeri \% 5 önemlilik düzeyinde anlamlı olup, denetçi değişikliği ve olumsuz denetim görüşü arasında anlamlı bir ilişki olduğunu göstermektedir.

Tablo 1: Olumsuz Denetim Raporu Sonrasındaki Bağımsız Denetçi Değişikliği Sıklığı (2003-2009)

Olumsuz Görüş Sonrası

Denetçi Değişikliği Zamanı
Toplam

\begin{tabular}{lr}
\hline Bir yıl & 13 \\
İki yıl & 4 \\
Üç yıl & 3 \\
Dört yıl & 4 \\
Beş yıl & 1 \\
\hline Denetçi Değişikliği Sayısı & 25 \\
Olumsuz Denetim Raporu Sayısı & 143 \\
\hline
\end{tabular}

Bu sonuç, ABD örneği üzerine Chow and Rice (1982), Avustralya örneğinde Craswell (1988) ve Hong Kong örneği üzerinde Gul, Lee and Lynn (1992) tarafından yapılan çalışmaların sonuçları ile paralellik gösterirken; ABD örneklemindeki Schwartz and Menon (1985) bulgularından farklı bir sonuçtur ${ }^{5}$.

\footnotetext{
${ }^{5}$ Denetçi değişikliği oranı, Chow ve Rice (1982) çalışmasında olumsuz görüşs sonrası 0.12 iken olumlu görüş sonrası 0.03; Craswell (1982) çalışmasında olumsuz görüş sonrası 0.06 iken olumlu görüş sonrası 0.02 olarak gerçekleşmiştir. Schwartz ve Menon (1985) çalışmasında ise bu oranlar; olumsuz görüş sonrası 0.15; olumlu görüş sonrası ise 0.33 olarak farklı yönde gerçekleşmiştir.
} 
Table 2: Olumsuz ve Olumlu Görüş Verilen Şirketlerde Denetçi Değişiklik Sıılığı

İlk Olumsuz Denetim Raporunu İzleyen Y11

\begin{tabular}{lc}
\hline Denetçi değişikliği & 13 \\
Denetçi değişikliği olmayan & 130 \\
Toplam & 143 \\
Denetçi değişiklik oranı & \multicolumn{2}{c}{0.09} \\
\hline \multicolumn{2}{c}{2} \\
Denetçi değişikliği & \multicolumn{2}{c}{ İlk Olumlu Denetim Raporunu İzleyen Yıl } \\
Denetçi değişikliği olmayan & 138 \\
Toplam & 140 \\
Denetçi değişiklik oranı & \multicolumn{2}{c}{0.01} \\
Ki-kare değeri (1 serbestlik derecesinde) & \multicolumn{2}{c}{$8.28^{*}$} \\
\hline
\end{tabular}

*\% 5 önemlilik düzeyinde anlamlı

\subsection{Olumsuz Denetim Görüşü Türüne Göre Denetçi Değişikliği}

İkinci analiz olarak, olumsuz denetim görüşü türüne bağlı olarak işletmelerin bağımsız denetçi değişikliği yapıp yapmadıkları incelenmiştir. Çalışmanın önceki kısmında açıklandığı üzere, Whittred (1980) çalışmasında, olumsuz denetim görüşündan kaynaklanabilecek maliyetlerin olumsuz denetim görüşünün önemlilik düzeyinin artan bir fonksiyonu olduğu belirtilmiştir. Buna göre, olumsuz denetim görüşü verilen aksaklıklar ne kadar çok önemli (ciddi) ise yöneticinin olumsuz denetim görüşünden kaçınma güdüsünün o kadar fazla olacağ 1 ve buna bağlı olarak denetçi değişikliğine gidebileceği belirtilmiştir. Bu durumu test etmek üzere, olumsuz denetim görüşü verilen şirketler Whittred (1980) ile Craswell (1988) çalışmasındaki gibi, olumsuz görüşün türüne göre; olumsuz, görüş bildirmekten kaçınma ve şartlı görüş şeklinde üçlü olarak sınıflandırılmıştır. Bu çerçevede, ilk olumsuz denetim görüşünü izleyen yıldaki denetçi değişikliği ile ilgili farklı türdeki olumsuz denetim görüşlerinin dağılımı Tablo 3'te sunulmuştur. Buna göre, olumsuz denetim görüşü türüne bağlı denetçi değiş̧ikliği oranının istatistiksel olarak anlamlı bir şekilde birbirinden farklı olmadığg görülmektedir. Buna göre, olumsuz denetim görüşü türüne bağlı denetçi değişikliği oranının istatistiksel olarak anlamlı bir şekilde birbirinden farklı olmadığı görülmektedir. Bir başka ifadeyle, ilk olumsuz denetim görüşünü izleyen yıldaki denetçi değişikliğinde, olumsuz denetim görüş türünün (olumsuz, görüş bildirmekten kaçınma, şartlı) bir etkisi bulunmamaktadir. 
Table 3: Olumsuz Denetim Görüşü Türüne Göre Denetçi Değişiklik Sıklığı

\begin{tabular}{lccc}
\hline & Olumsuz & $\begin{array}{c}\text { Görüşs } \\
\text { Bildirmekten } \\
\text { Kaçınma }\end{array}$ & Şartlı \\
\hline Denetçi değişikliği & 0 & 1 & 12 \\
Deneţi değişikliği olmayan & 0 & 8 & 122 \\
Toplam & 0 & 9 & 134 \\
Denetçi değişiklik oranı & 0.00 & 0.11 & 0.09 \\
\hline Ki-kare değeri (1 serbestlik derecesinde) & 0.05 & &
\end{tabular}

\subsection{Denetçi Değişikliği Sonrası Olumsuz Denetim Görüşünün İzleyen Yılda Tekrarlanma Sıklığı}

Literatürde, olumsuz denetim görüşü ve bağımsız denetçi değişikliği arasındaki ilişki ile ilgili argüman; denetçinin değiştirilerek olumlu görüş elde edilebileceği ve böylece verilmesi muhtemel olumsuz denetim görüşünün maliyetlerinden kaçınılabileceği varsayımına dayandırılmaktadır (Chow and Rice, 1982; Schwartz and Menon, 1985; Craswell, 1988). Bu durumu test etmek amaciyla, ilk olumsuz denetim görüşünü izleyen y1lda şirketlerin olumsuz denetim görüşü alma sıklıkları incelenmiş ve sonuçlar Tablo 4'te sunulmuştur.

Tablo 4'te görüldüğü üzere, ilk olumsuz denetim görüşünü izleyen yılda bağımsız denetçi değiştirmek suretiyle şirketlerin olumlu denetim görüşü elde etme oranının denetçi değişikliğine gitmeyen şirketlerin oranından daha yüksek olduğu anlaşılmaktadır. Ancak, Ki-kare test sonuçları; bağımsız denetçi değişikliğine giden şirketlerin olumlu denetim görüşü elde etme oranının (0.54), denetçi değişikliğine gitmeyen şirketlerin oranı (0.42) ile karşılaştırıldığında, \% 5 önemlilik düzeyinde istatistiksel olarak anlamlı bir farklılığın olmadığını göstermektedir.

Table 4: Denetçi Değişikliğini İzleyen Yılda Olumsuz Denetim Görüşünün Tekrarlanma Siklığı

\begin{tabular}{lcc}
\hline & Denetçi Değiştiren Şirketler & $\begin{array}{c}\text { Denetçi Değiştirmeyen } \\
\text { Şirketler }\end{array}$ \\
\hline Olumsuz Görüş & 6 & 77 \\
Olumlu Görüş & 7 & 53 \\
Toplam & 13 & 130 \\
Olumlu Görüş Oranı & 0.54 & 0.41 \\
Ki-kare değeri (1 serbestlik derecesinde) & 0.83 & \\
\hline
\end{tabular}

ABD örneğindeki Chow and Rice (1982) çalışma sonuçları ile tutarlı olan bu sonuç, Avustralya örnekleminde yapılan Craswell (1988) çalışma sonuçları ile farklılık göstermektedir. Dolayısıyla, Tablo 4'teki sonuç, ilk olumsuz denetim görüşü sonrasında 
denetçi değiştiren şirketlerin, denetçi değiştirmeyen şirketlerle karşılaştırıldığında, izleyen yılda olumlu denetim raporu alma yönünden önemli bir farklılık göstermediği anlamına gelmektedir.

\subsection{Denetçi Değişikliği Sonrası Olumsuz Görüşün Denetçi Değişikliği Öncesindeki Olumsuz Görüş Türü ve Denetim Firması Büyüklüğü ile İlişskisi}

Craswell (1988) çalışmasında, olumsuz görüş verilme olasılığının denetçi değişikliği öncesinde verilen olumsuz raporun ve denetim firmasının türü ile ilişkili olabileceği belirtilmiştir. Bu ilişkiyi test etmek amacıyla, çalışmanın önceki kısımlarındaki kullanılan veri setindeki 'ilk olumsuz denetim raporu' şeklinde kısıtlama ortadan kaldırılarak (13 denetçi değişikliği), bir olumsuz denetim raporunu izleyen yılda ilave 12 denetçi değişikliği daha belirlenebilmektedir. $\mathrm{Bu}$ kapsamda, 20 şirket'e ait toplam 25 denetçi değişikliği belirlenmektedir. Dolayısıyla, Craswell (1988) çalışmasına benzer şekilde, söz konusu denetçi değişikliklerini izleyen yılda olumlu denetim görüşünün denetçi değişikliği öncesinde verilen olumsuz denetim görüşünün yapısı ve denetim firması türü (büyüklüğü) ile ilişkili olup olmadığı test edilmiş ve sonuçlar Tablo 5 ve 6'da sunulmuştur. Bu çerçevede, denetçi değişikliği sonrasındaki denetim görüşünün denetçi değişikliği öncesindeki olumsuz denetim görüş türüne göre dağılımı Tablo 5'te gösterilmiştir. Tablo 5'te görüldüğü üzere, 1 serbestlik derecesindeki Ki-kare değeri 1.92 olup, 0.05 önemlilik düzeyinde istatistiksel olarak anlamlı değildir. Bu sonuç, Craswell (1988) çalışma sonucu ile benzer bir sonuç olup, denetçi değişikliği sonrasında şirketlerin olumlu görüş alma oranının denetçi değişikliği öncesindeki olumsuz denetim görüş türünden bağımsız olduğunu göstermektedir.

Table 5: Denetçi Değişikliği Öncesi Olumsuz Görüş Türüne Göre Sonrasındaki Görüş Siklı̆̆ 1

Denetçi Değişikliği Öncesindeki Olumsuz Görüş Türü

\begin{tabular}{lcccc}
\hline $\begin{array}{l}\text { Denetçi Değişikliği Sonrası } \\
\text { Denetim Raporu Türü }\end{array}$ & Olumsuz & $\begin{array}{c}\text { Görüş } \\
\text { Bildirmekten } \\
\text { Kaçınma }\end{array}$ & Şartlı & Toplam \\
\hline Olumsuz & 0 & 3 & 13 & 16 \\
Olumlu & 0 & 0 & 9 & 9 \\
Toplam & 0 & 3 & 0.41 & 25 \\
Olumlu Görüş Oranı & 0.00 & & 0.36 \\
Ki-kare değeri (1 s.d.) & 1.92 & & & \\
\hline
\end{tabular}


Table 6: Denetim Firması Türüne Göre Denetçi Değişikliği Sonrasındaki Olumsuz Görüş Siklı̆̆ 1

Denetçi Değişikliği Sonrasındaki

Denetim Firması Türü

\begin{tabular}{lccc}
\hline $\begin{array}{lcc}\text { Denetçi Değişikliği Sonrası } \\
\text { Denetim Raporu Türü }\end{array}$ & Dört Büyükler & Diğerleri & Toplam \\
\hline Olumsuz & 2 & 14 & 16 \\
Olumlu & 5 & 4 & 9 \\
Toplam & 7 & 18 & 25 \\
Olumlu Görüş̧ Oranı & 0.71 & 0,22 & 0.36 \\
Ki-kare değeri (1 s.d.) & $5.30^{*}$ & & \\
\hline
\end{tabular}

*\% 5 önemlilik düzeyinde anlamlı

Bir başka ifadeyle, denetçi değişikliği öncesindeki raporun türünün olumsuz, görüş bildirmekten kaçınma veya şartlı denetim görüşü olmasının, denetçi değişikliği sonrasında olumlu denetim görüşü alınması yönünden istatistiksel olarak anlamlı bir farklılık oluşturmamaktadır.

Denetçi değişikliğini izleyen yılda olumlu denetim görüşü alınmasının bağımsız denetim firmasının türüne göre farklılık gösterip göstermediği Tablo 6' da sunulmuştur. Tablo 6'da görüldüğü üzere; denetçi değişikliğini izleyen yılda 4 büyükler dişındaki diğer denetim firmalarınca (diğerleri) verilen olumsuz denetim görüşü oranı (0.78), 4 büyük denetim firmasınca (4 büyükler) verilen olumsuz denetim görüşü oranı (0.29)'dan istatsistiksel olarak anlamlı bir şekilde (0.05 önemlilik düzeyinde) farklıdır. Craswell (1988) bulgusundan farklılık gösteren bu sonuç, denetçi değişikliğinin hemen sonrasında olumlu görüş verilmesinin denetçi türü ile ilişkili olduğunu göstermektedir. Bir başka ifadeyle, olumsuz görüş nedeniyle bağımsız denetçi değişikliğine giden şirketlerin denetçi değişikleri, 4 büyük denetim firmaları yönünde yapılmıştır.

\section{SONUÇLAR VE GELECEK ARAŞTIRMALAR İÇİN ÖNERİLER}

Literatürde, olumsuz denetim görüşü sonrasında denetçi değişikliği yapılmak suretiyle olumlu bir denetim görüşü elde edilebileceği ve olumsuz denetim görüşü sonrasındaki muhtemel maliyetlerden kaçınılabileceği argümanı önemli bir varsayım olarak kabul görmektedir. Bu kapsamda, olumsuz denetim görüşü ve denetçi değişikliği arasında anlamlı bir ilişkinin olup olmadığını araştıran bu çalışmada, Avusturalya örneklemindeki Craswell (1988) çalışması ile benzer yöntem kullanılmak suretiyle, Türkiye gibi gelişmekte olan bir ülkede bu ilişkinin nasıl olduğu araştırılmıştır. Elde edilen araştırma bulguları, olumsuz denetim görüşleri ve denetçi değişiklikleri arasında istatistiksel olarak önemli sayılan bir düzeyde (0.05 önemlilik düzeyinde) pozitif bir ilişkinin bulunduğunu göstermektedir. Önceki çalışma sonuçları (Chow and Rice, 1982; Craswell, 1988; Gul et al., 1992; Citron and Tafler, 
1992; Krsihnan et al., 1996; Lennox, 2000; Vanstraelen, 2003) ile benzer olan bu sonuç, Schwartz and Menon (1985) bulgularından farklı bir sonuçtur.

İlk olumsuz denetim görüşü sonrasında denetçi değiştiren şirketlerin olumlu denetim raporu alma yönünden denetçi değiştirmeyen şirketlerle yapılan karşılaştırmasında; izleyen yılda olumlu denetim raporu alma yönünden önemli bir farklılık göstermediği (Schwartz and Menon, 1985 bulgusu ile paralel olarak) sonucu elde edilmiştir. Ayrıca, denetçi değişikliği sonrasında şirketlerin olumlu görüş alma oranının; denetçi değişikliği öncesindeki olumsuz denetim görüş türünden bağımsız olduğu (Craswell, 1988 ile paralel olarak), ancak denetim firması büyüklüğü (denetçi türü) ile ilişkili olduğu (Craswell,1988'den farklı olarak) yönünde bulgular elde edilmiştir.

Literatürde olumsuz denetim görüşü ve denetçi değişikliği arasındaki ilişkiyi farklı yöntemler kullanarak araştıran çeşitli çalışmalar bulunmakla birlikte, Türkiye gibi gelişmekte olan ve bağımsız dış denetim kalitesinin sorgulandığı ülkelerde bu nitelikte çalışma sayısı sınırlıdır. Bu kapsamda, bu çalışmada, sadece denetçi değişikliğini etkileyen en önemli faktörlerden biri olarak kabul edilen olumsuz denetim görüşünün etkisi incelenmiştir. Ancak, denetçi denetçi değişikliği üzerinde etkisi olabilecek; yönetimdeki değişiklikler, denetim ücretleri, işletme büyüklüğü, finansal sıkıntı, şirket birleşmeleri gibi değişkenler bu çalışmada incelenmemiştir. Literatürde bu çerçevede yapılan çeşitli çalışmalar bulunmakla birlikte, Türkiye'de söz konusu değişkenler kullanılarak yapılan çalışmaya rastlanmadığından, Türkiye örneklemindeki gelecekteki çalışmalarda denetçi bağımsızlığına etkisi olabilecek bu değişkenlerin incelenmesi önem taşımaktadır. Ayrıca, denetçi değişikliklerinin çeşitli analitik teknikler yardımıyla tahmin edilmesi, gelecekte yapılması gereken muhtemel çalışmalar açısından literatüre önemli katkılar sağlayacaktır.

\section{KAYNAKLAR}

Burton, John C. - Roberts, William. (1967), "A Study of Auditor Changes”, The Journal of Accountancy, Vol. 123, No. 4, pp. 31-36.

Carpenter, Charles G. - Strawser, Robert H. (1971). "Displacement of Auditors When Clients Go Public” The Journal of Accountancy, Vol. 131, No. 6, pp. 55-58.

Chow, Chee W. - Rice, Steven J. (1982), “Qualified audit Opinions and Auditor Switching”, The Accounting Review, Vol. LVII, No. 2, pp. 326-335.

Citron, David B. - Taffler, Richard J. (1992), “The Audit Report Under Going Concern Uncertainties: An Empirical Analysis", Accounting and Business Research, Vol. 22, No. 88 , pp. 337-345.

Craswell, Allen T. (1988), "The Association Between Qualified Opinions and auditor Switches", Accounting and Business Research, Vol. 19, No. 73, pp. 23-31. 
Deangelo, Linda E. (1981), “Auditor Independence, 'Low-Balling' and Disclosure Regulation”, Journal of Accounting and Economics, Vol. 3, No. 2, pp. 113-127.

Defond, Mark L. - Raghunandan, Kannan - Subramanyam, K.R. (2002), "Do Non-Audit Service Impair Auditor Independence? Evidence From Going Concern Audit Opinions”, Journal of Accounting Research, Vol. 40, No. 4, pp. 1247-1274.

Dye, Ronald A. (1991), "Informationally Motivated Auditor Replacement", Journal of Accounting and Economics, Vol. 14, No. 4, pp. 347-374.

Gul, Ferdinand A. - Lee, D.S. - Lynn Margulis (1992), “A Note on Audit Qualification and Switches: Some Further Evidence from a Small Sample Study", Journal of International Accounting, Auditing \& Taxation, Vol. 1, No. 1, pp. 111-120.

Haskins, Mark E. - Williams, David D. (1990), “A Contingent Model of Intra Big Eight Auditor Changes", Auditing: A Journal of Practice and Theory, Vol. 9, No. 3, Pp. 55-74.

Hudaib, Mohammad. - Cooke, T.E. (2005), “The Impact of Managing Director Changes and Financial Distress on Audit Qualification and Auditor Switching”, Journal of Business Finance \& Accounting, Vol. 32, No. 9-10, pp. 1703-1739.

Krishnan, Jagan - Krishnan, Jayanthi - Stephens, Ray G. (1996), “The Simultaneous Relation Between Auditor Switching and Audit Opinion: An Empirical Analysis", Accounting and Business Research, Vol. 26, No. 3,pp. 224-236.

Lennox, Clive. (2000), "Do Companies Successfully Engage in Opinion-Shopping? Evidence from the U.K.", Journal of Accounting and Economics, Vol. 29, No. 3, p. 321-337.

Schwartz, Kenneth B. - Menon, Krishnagopal. (1985), “Auditor Swithes by Failing Firms”, The Accounting Review, Vol. LX, No. 2, pp. 248-261.

Sriram, Ram S. (1990), "Changing Auditors and the Influence of Client Specific Attributes: An Analysis”, Vol. 6, No. 4,pp. 104-108.

Teoh, Siew. H. (1992), “Auditor Independence, Dismissal Threats and the Market Reaction to Auditor Switches”, Journal of Accounting Research, Vol. 30, No. 1, pp. 1-23.

T.C. Resmi Gazete (18 Mart 2014. Sayı: 28945). Türkiye Denetim Standartları Tebliği, No: 31, http:www.resmigazete.gov.tr /eskiler/2014/03/20140318-12.htm, 20.02.2014.

Vanstraelen, Ann. (2003), "Going-Concern Opinions, Auditor Switching, and Self-Fulfilling Prophecy Effect Examined in the Regulatory Context of Belgium", Journal of Accounting and Finance, Vol. 18, No. 2, pp. 231-253.

Warren, Carl S. (1980), "Uniformity of Auditing Standars: A Replication", Journal of Accounting Research, Vol. 18, No. 1, pp. 312-324.

Whittred, Greg P. (1980), "Audit Qualifications and the Timeliness of Corporate Annual Reports”, The Accounting Review, Vol. LV, No. 4, pp. 563-577. 
Willenborg, Michael (1999), "Empirical Analysis of the Economic Demand for Auditing in the Initial Public Offerings Market”, Journal of Accounting Research, Vol. 37, No. 1, pp. 225-239.

Williams, David D. (1988), "The Potential Determinants of Auditor Change", Journal of Business Finance \& Accounting, Vol. 15, No. 2, pp. 243-261.

Wines, Graeme. (1994), “Auditor Independence, Audit Qualifications and the Provision of Non-Audit Services: A Note", Accounting and Finance, Vol. 34, No. 1, pp. 75-86.

Woo, E-Sah. - KOH, Hian Chye. (2001), "Factors Associated with Auditor Changes: A Singapore Study", Accounting and Business Research, Vol. 31, No. 2, pp. 133-144. 